\title{
Analysis of Entrepreneurship Interest on Business Productivity
}

\author{
Nanang Adie Setyawan*, Bagus Yunianto Wibowo, Mellasanti Ayuwardani \\ Jurusan Administrasi Bisnis Politeknik Negeri Semarang \\ *Penulis Korespondensi: nanangadie@polines.ac.id
}

\begin{abstract}
This study was conducted to determine the interest in entrepreneurship and business productivity of Semarang State Polytechnic students during the covid-19 pandemic. Respondents in this study were Semarang State Polytechnic students who had a business in the middle of their learning on campus totaling 100 students. This study uses confirmatory factor analysis and maximum likelihood estimation techniques on SEM (Structural Equations Modeling) from the AMOS 24.0 statistical package (Analysis of Moment Structure). The data collection technique used a questionnaire with a differential semantic scale. The parameter estimation results are in accordance with the hypothesis that entrepreneurial understanding significantly affects entrepreneurial interest with an estimated standardized coefficient value of 0.534 and P-Value ***, as well as entrepreneurship training has a positive effect on entrepreneurial interest with an estimated standardized coefficient value of 0.503 and P-Value *** and interest in entrepreneurship significantly affects business productivity with an estimated standardized coefficient of 0.361 and P-Value ***. From this research, it can be concluded that in the midst of the current covid-19 pandemic, students who are engaged in the world of entrepreneurship need to increase their training and understanding related to entrepreneurship, especially with the current digitalization era which is growing rapidly, there needs to be innovations that can make them survive in a better direction according to the times.
\end{abstract}

Keywords: Understanding of Entrepreneurship, Entrepreneurship Training, Interest in Entrepreneurship, Business Productivity.

\begin{abstract}
ABSTRAK
Penelitian ini dilakukan untuk mengetahui minat berwirausaha dan produktivitas usaha mahasiswa Politeknik Negeri Semarang di tengah pandemi covid-19. Responden dalam penelitian ini adalah mahasiswa Politeknik Negeri Semarang yang mempunyai usaha ditengah pembelajaran mereka di kampus berjumlah 100 mahasiswa. Penelitian ini menggunakan teknik analisis faktor konfirmatori dan maximum likehood estimation pada SEM (Structural Equations Modeling) dari paket statistik AMOS 24.0 (Analysis of Moment Structure). Teknik pengumpulan data menggunakan kuesioner dengan skala semantik diferensial. Hasil estimasi parametersesuai dengan hipotesis bahwa pemahaman kewirausahaan secara signifikan mempengaruhi minat berwirausaha dengan nilai estimasi koefisien standardized 0,534 dan $P$-Value ***, begitu pula dengan pelatihan kewirausahaan berpengaruh positif terhadap minat berwirausaha dengan nilai estimasi koefisien standardized 0,503 dan $P$-Value $* * *$ serta minat berwirausaha secara signifikan mempengaruhi produktivitas usaha dengan nilai estimasi koefisien standardized 0,361 dan P-Value ***. Dari penelitian ini dapat disimpulkan bahwa ditengah pandemi covid-19 saat ini para mahasiswa yang bergelut di dunia kewirausahaan perlu menambah pelatihan dan pemahaman mereka terkait kewirausahaan apalagi dengan era digitalisasi saat ini yang berkembang pesat perlu ada inovasiinovasi yang bisa membuat mereka tetap bertahan dan berkembang ke arah yang lebih baik sesuai dengan jaman.
\end{abstract}

Kata Kunci: Pemahaman Kewirausahaan, Pelatihan Kewirausahaan, Minat Berwirausaha, Produktivitas Usaha. 


\section{PENDAHULUAN}

\section{Latar Belakang}

Perguruan tinggi diharapkan mampu menciptakan lulusan yang dapat mengisi kekurangan lapangan kerja saat ini. Berwirausaha merupakan pilihan yang tepat dan logis, sebab selain peluang lebih besar untuk berhasil, sesuai dengan program pemerintah dalam percepatan penambahan UKM yang hebat dan berlandaskan pada ilmu pengetahuan yang diterapkan dan teknologi terkini (Ni Made Sintya, 2019). Pengetahuan kewirausahaan mendorong nilai- nilai wirausaha terutama bagi mahasiswa diharapkan menumbuhkan jiwa berwirausaha, minat mahasiswa sangat dibutuhkan bagi mahasiswa yang ingin berwirausaha agar mampu mengidentifikasi peluang usaha, kemudian mempergunakan peluang usaha untuk menciptakan peluang kerja baru. Minat mahasiswa dan pengetahuan mereka tentang kewirausahaan diharapkan mampu membentuk kecenderungan mereka untuk membuka usaha baru di masa yang akan datang.

Kewirausahaan merupakan perhatian yang sangat penting dalam menghadapi tantangan globalisasi yaitu kompetisi ekonomi global dalam hal produktivitas dan inovasi (Yulius David \& Andi. 2016). Dengan begitu mahasiswa dapat meningkatkan minat berwirausaha dan produktivitas usaha agar mendapatkan keunggulan bersaing dan mampu bersaing di pasar dunia yang terus tumbuh dan bergerak cepat, sehingga pengangguran terdidik berkurang apabila perguruan tinggi mampu mengarahkan peserta didik dan alumninya untuk membuat lapangan kerja. Didukung rendahnya pemahaman kewirausahaan mahasiswa untuk berminat menjadi wirausaha, merupakan pemikiran yang harus ditindak lanjuti bagi dunia pendidikan. Mahasiswa merupakan kelompok intelektual di masyarakat sudah seharusnya menjadi pelopor dalam mengembangkan semangat kewirausahaan. Stauffer, D. (2016) menyatakan bahwa dengan bekal pendidikan tinggi yang diperoleh dibangku kuliah dan idealisme yang terbentuk maka lulusan Perguruan Tinggi diharapkan mampu mengembangkan diri menjadi wirausahawan.

Pada saat ini di Indonesia menurut data terbaru diperkirakan hanya sekitar 570.339 orang atau $0,24 \%$ dari jumlah penduduk yang berjumlah 270 juta jiwa yang secara aktif menjadi wirausahawan; sedangkan sejumlah pakar menyatakan untuk menjadi negara yang sejahtera dan makmur, suatu negara harus memiliki minimum dua persen wirausahawan dari total penduduk. Data di atas terpapar masih dibutuhkan sekitar sepuluh kali jumlah wirausahawan di Indonesia agar angka minimal persentase wiraswasta terpenuhi. Data lain juga menunjukkan bahwa minat masyarakat untuk menjadi wirausaha juga masih rendah; lulusan Perguruan Tinggi yang berminat menjadi wirausaha hanya 6,4\%, sementara untuk tingkat SLTA jumlahnya hanya $22,4 \%$. Padahal potensi kelompok pemuda untuk bisa menjadi wirausaha saat ini relatif besar, dengan tingkat kelulusan Sarjana mencapai tiga ratus ribu orang dan lulusan SMU mencapai dua setengah juta orang per tahun.

Di sisi lain, saat ini telah terjadi perubahan besar dalam lingkungan bisnis sebagai dampak dari kemajuan yang nyata dan masif dari teknologi informasi. Masyarakat Indonesia yang dahulu sebagian besar beraktivitas di bidang pertanian dan industri, saat ini telah bergeser ke bidang teknologi informasi. Era pertanian dan era industri telah kehilangan nilai tambahnya dan sekarang bidang teknologi informasi menjadi pemberi nilai tambah besar bagi banyak kegiatan produktif. Kegiatan bisnis juga banyak tersentuh dan dipengaruhi oleh kemajuan tersebut. Komunikasi lewat media sosial elektronik dan kegiatn pemasaran via online telah mengubah metode orang untuk berbisnis. Saat ini kegiatan bisnis, termasuk yang dilakukan banyak wirausahawan, tidak dapat lepas dari dogma teknologi informasi, mulai dari proses bisnis online, proses transaksi via online, komunikasi lewat whatapp ataupun pesan langsung, sampai pelayanan purna jual yang dapat dilakukan lewat beragam media sosial elektronik. 
Tidak ada bidang bisnis yang tidak tersentuh oleh aplikasi teknologi informasi; generasi muda, termasuk mahasiswa, mempunyai peluang bagus untuk memanfaatkan momentum perkembangan teknologi informasi tersebut saat berniat menjadi seorang wirausahawan.

Permasalahan utama ialah masih rendahnya minat mahasiswa untuk berwirausaha. Sebagian besar mahasiswa berorientasi sebagai pencari kerja (job seeker), bukan pencipta lapangan kerja (job creator). Kondisi ini dialami oleh mahasiswa di Politeknik Negeri Semarang, dengan asumsi bahwa membuat lapangan kerja baru berbanding terbalik dengan jumlah pencari kerja. Minat berwirausaha dipengaruhi oleh dua faktor, yaitu faktor internal dan ekternal orang tersebut. Dalam penelitian ini yang mempengaruhi minat berwirausaha mahasiswa difokuskan pada faktor internal, yaitu: faktor pemahaman kewirausahaan dan faktor pelatihan kewirausahaan.

\section{Perumusan Masalah}

Meningkatkan minat berwirausaha pada mahasiswa kewirausahaan di Politeknik Negeri Semarang dibutuhkan cara dengan mengoptimalkan pemahaman kewirausahaan untuk membekali mahasiswa, serta pelatihan kewirausahaan yang dapat menjadi penguat terbentuknya peningkatan produktivitas usaha. Berdasarkan studi pada penelitian sebelumnya, terdapat beberapa masalah yang berkaitan dengan pemahaman kewirausahaan dan pelatihan kewirausahaan yang mampu meningkatkan minat berwirausaha dan produktivitas usaha mahasiswa. Sehingga diperlukan penyelesaian masalah sebagai berikut : Bagaimana pengaruh pemahaman kewirausahaan, pelatihan kewirausahaan terhadap minat berwirausaha dan Bagaimana pengaruh minat berwirausaha terhadap produktivitas usaha

\section{Tujuan Penelitian}

Penelitian ini bertujuan mengetahui bagaimana minat berwirausaha meningkatakan produktivitas usaha mahasiswa politeknik negeri semarang melalui faktor pemahaman kewirausahaan; faktor pelatihan kewirausahaan di masa pandemi covid-19, Penelitian dipercaya dapat memberikan kontribusi bagi perkembangan ilmu pengetahuan, bermanfaat bagi para mahasiswa khususnya mahasiswa politeniknik negeri semarang guna meningkatkan minat berwirausaha di masa pandemi covid-19.

\section{TINJAUAN PUSTAKA}

\section{Minat Berwirausaha}

Secara umum kata 'minat' mempunyai arti kecenderungan yang relatif menetap pada diri seseorang untuk tertarik pada suatu bidang tertentu dan merasa senang berkecimpung dalam berbagai kegiatan yang berkaitan dengan bidang itu; maka individu yang berminat menjadi wirausahawan secara umum merasa terpikat dan cenderung senang dengan berwirausaha. Individu yang berminat menjadi wirausahawan secara kognitif mempunyai pemahaman yang cukup akan keuntungan, tantangan, dan resiko yang akan dihadapi, merasa senang dengan pilihannya (afektif), dan akan bertindak (konatif) seperti yang diyakininya. Hal tersebut menunjukkan variabel independen (Efikasi Diri) mempunyai hubungan yang positif dan signifikan dengan variabel dependen niat (Niat Berwirausaha). Hasil ini selaras dengan temuan riset beberapa penelitian yang menyatakan adanya hubungan positif dan nyata antara dua variabel tersebut (Asep Munawar, 2018; Josia Sanchaya Hendrawan, 2017).

Minat berwirausaha merupakan keinginan, ketertarikan, serta kesediaan guna bekerja keras atau berkemauan keras untuk berdikari atau berusaha untuk memenuhi kebutuhan hidupnya tanpa merasa takut dengan resiko yang akan terjadi, serta berkemauan keras untuk belajar dari kegagalan. Bagi sejumlah peneliti, minat berwirausaha ialah prediktor yang reliabel 
dari perilaku kewirausahaan menurut Ni Made Sintya (2019). sedangkan peneliti lain menganggap minat berwirausaha lebih merupakan tendensi individu untuk melakukan tindakan berwirausaha dengan menciptakan produk baru melalui peluang bisnis dan pengambilan risiko (Setyawan, 2021). Sejumlah peneliti lainnya menyatakan adanya beberapa istilah lain untuk minat berwirausaha, seperti orientasi karir, wirausahawan yang baru lahir, dan lainnya; mereka mengartikan minat berwirausaha sebagai orientasi mental seperti keinginan yang kuat, impian, dan harapan untuk mempengaruhi pilihan mereka melakukan kegiatan kewirausahaan (Asep Munawar, 2018).

\section{Pelatihan Kewirausahaan}

Aditya dan Ketut (2016) mengemukakan Pelatihan ialah proses kegiatan pembelajaran antara pengalaman untuk mengembangkan pola perilaku seseorang dalam bidang pengetahuan, keterampilan, atau sikap untuk mencapai standar yang diharapkan. Dengan demikian, pelatihan adalah proses merekayasa perilaku pesrta didik dalam aspek pengetahuan, sikap dan keterampilan untuk meningkatkan keterampilan dalam upaya memenuhi kebutuhan hidup.

Lestari, dkk (2016) mengungkap terdapat aspek dari kewirausahaan yang mampu diajarkan yaitu bisnis dan keterampilan manajemen dan ada aspek kewirausahaan yang tidak mampu untuk diajarkan yaitu kreativitas dan pemikiran inovatif kecuali melalui pengalaman praktek. Dari penelitian yang dilakukannya menghasilkan bahwa ketika sistem pendidikan dan pelatihan menggabungkan kreativitas dan kemampuan manajerial kewirausahaan ke dalam metodologi pengajaran, pola pikir dan keterampilan terikat lebih erat dengan "seni" kewirausahaan Berdasarkan penjelasan di atas, ditemukan bahwa terdapat peranan dari pendidikan dan pelatihan kewirausahaan dalam menumbuhkan semangat kewirausahaan.

Dalam prakteknya, program pendidikan dan pelatihan kewirausahaan/ diklasifikasikan menjadi dua kategori program yaitu education program (program pendidikan) dan training program (program pelatihan). Keduanya dibedakan dari tujuan dan hasil dari masing-masing program. Academic Entrepreneurship Education (EE) Program cenderung fokus untuk membangun pengetahuan dan keterampilan tentang kewirausahaan, termasuk tujuan kewirausahaan. Sedangkan Entrepreurship Training (ET) Program cenderung fokus untuk membangun pengetahuan dan keterampilan secara eksplisit dalam persiapan untuk memulai suatu usaha (Diajeng Galuh Chandra Kirana, 2018).

\section{Pemahaman Kewirausahaan atau Efikasi Diri Kewirausahaan}

Secara umum, efikasi diri kewirausahaan merupakan kondisi dimana individu percaya bahwa suatu perilaku mudah atau sulit untuk dilakukan. Ini mencakup juga pengalaman masa lalu disamping rintangan-rintangan yang ada, yang dipertimbangkan oleh individu tersebut $(\mathrm{Ni}$ Made Sintya, 2019). Pendapat lain mengemukakan bahwa efikasi diri kewirausahaan adalah kepercayaan seseorang atas kemampuan dirinya, Efikasi diri kewirausahaan adalah kepercayaan seseorang atas kemampuan dirinya untuk menyelesaikan suatu pekerjaan. Atau dengan kata lain, kondisi motivasi seseorang yang lebih didasarkan pada apa yang mereka percaya daripada apa yang secara objektif benar; persepsi pribadi seperti ini memegang peranan penting dalam pengembangan minat seseorang (Mahesa dan Rahardja,2016).

Josia Sanchaya Hendrawan (2017) menyatakan kesamaan efikasi diri dengan kepercayaan diri (self confidence); dalam risetnya tentang pengaruh efikasi diri dengan melihat faktor gender, mereka menyatakan adanya hubungan yang kuat antara keyakinan dan kepercayaan diri seseorang bahwa dia dapat melakukan pekerjaannya dengan niat mereka untuk membuka wirausaha.

Variabel efikasi diri kewirausahaan terdiri dari empat dimensi, yakni kapabilitas seseorang untuk mampu mengambil kesempatan bisnis, mampu melihat peluang pasar, 
mengoptimalkan sumber daya manusia dan modal yang ada untuk meraih kesempatan tersebut. Dimensi kedua adalah ketenangan, yang diartikan sebagai kemampuan seseorang untuk mengendalikan emosi dan perasaannya, yang biasanya digunakan saat menghadapi situasi dan persoalan di dunia bisnis. Dimensi ketiga adalah ketekunan atau kemampuan seseorang untuk bekerja di bawah tekanan dan mampu melakukan skala prioritas. Sedangkan dimensi keempat adalah fokus pada tugas yang berkaitan dengan detil tugas serta waktu dan skedul untuk mencapainya (Sukirman, 2017).

\section{Produktivitas Usaha}

Ni Made Sintya (2019) mengatakan suatu usaha yang ingin mempunyai keunggulan dalam persaingan bisnis perlu menciptakan model bisnis yang dirancang dengan cermat, Menurutnya bahwa model bisnis merupakan nilai yang diciptakan oleh pengusaha kemudian didstribusikan kepada konsumen dan menuju pada tahap pembayaran yang menghasilkan keutungan. Setyawan (2021) Mengemukakan tantangan terbesar dalam pengukuran produktivitas adalah sifat dari kinerja sangat multi dimensional sehingga menjadikan pengukuran tunggal belum mampu memberikan pemahaman secara penuh dan tingkat kerumitan yang tinggi dari sebuah konstruk merupakan sandungan dalam pengukuran. Akan tetapi Yulius David Andi (2016) mengemukakan dalam pengukuran produktivitas, persepsi dan objektifitas dapat dipakai untuk menganalisa dan mengukur produktivitas usaha. Kinerja pengusaha merupakan hasil dari strategi perusahaan yang telah dilaksanakan dan dapat diukur, Setyawan (2021) mengungkapkan ada beberapa indikator variabel produktivitas usaha sebagai acuan dalam sebuah penelitian meliputi: Pertumbuhan Pelanggan, Pertumbuhan Penjualan, Pertumbuhan Keuntungan, Pertumbuhan Aset.

Dari paparan diatas model penelitian ini ialah sebagai berikut:

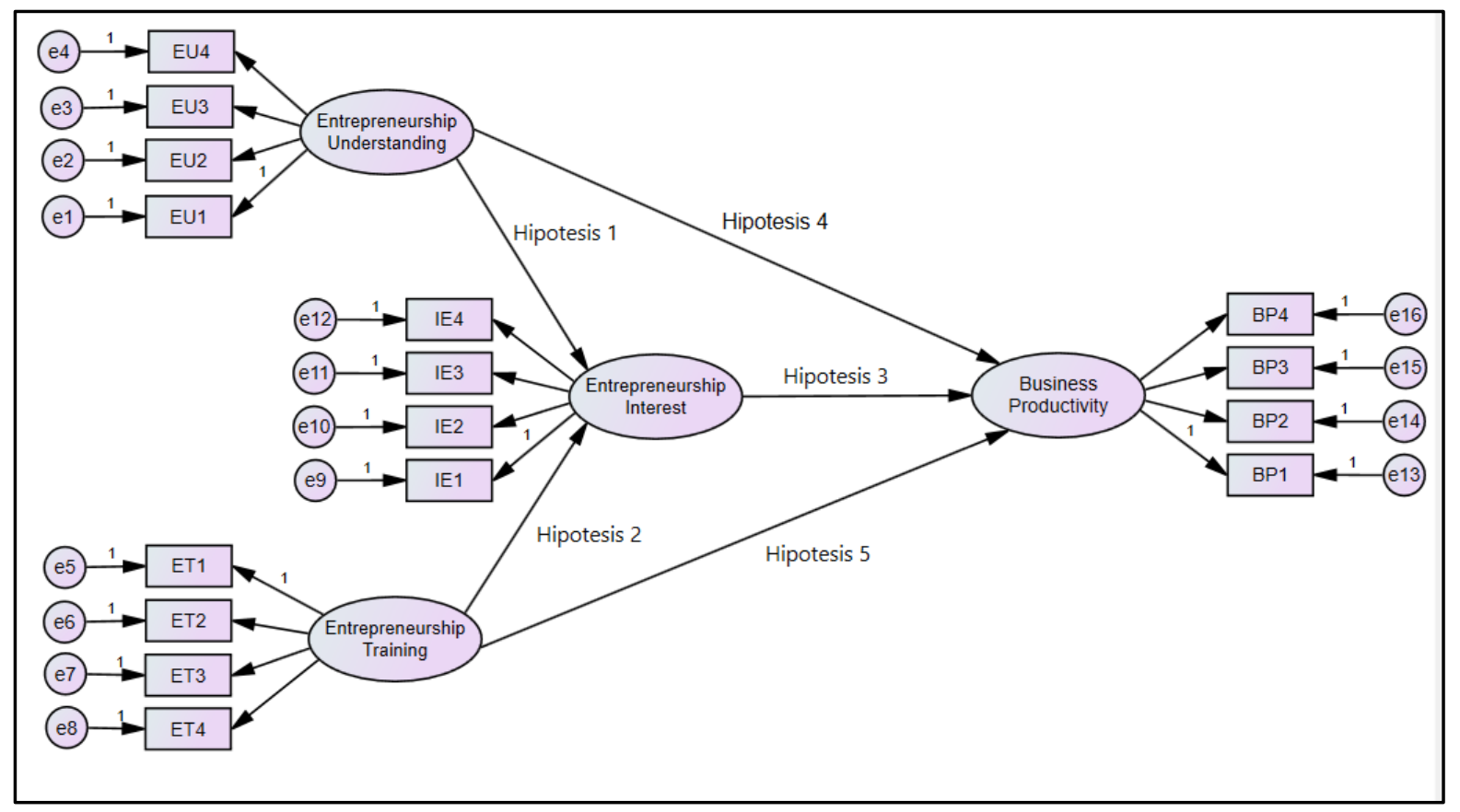

Sumber: Data primer yang diolah (2021)

Gambar 1. Model Penelitian 


\section{METODE PENELITIAN}

Jenis data yang digunakan dalam penelititan ini adalah data primer yang diolah secara kuantitatif. Adapun sumber data dalam penelitian ini menggunakan data primer dan data sekunder. Data primer diperoleh dengan cara survei dan wawancara dengan menggunakan kuisioner dengan skala semantik differensial kepada para mahasiswa politeknik negeri semarang yang berjumlah 100 responden, penentuan responden dalam penelitian ini menggunakan teknik non probability sampling yaitu insidential sampling merupakan teknik yang digunakan untuk penentuan sampel menggunakan pertimbangan tertentu agar sampel tersebut benar-benar dapat mempresentasikan populasi, Teknik analisis data yang digunakan dalam penelitian ini adalah teknik analisis faktor konfirmatori dan maximum likehood estimation pada SEM dan uji asumsi klasik (uji Normalitas, uji Measurement Model, uji Goodness of Fit, dan uji hipotesis) dari dari paket statistik AMOS 24.0 (Analysis of Moment Structure) (Hair, et al, 2014)

Langkah-langkah yang harus dilakukan yaitu meliputi: (1) Pengembangan model berdasarkan teori, (2) Menyusun diagram jalur dan persamaan struktural, (3) Memilih jenis input matrik dan estimasi model yang diusulkan, (4) Menilai identifikasi model struktural (5) Menilai Kriteria Goodness of fit, (7) Interpretasi dan modifikasi model (Ghozali, 2017). Dalam menilai kriteria goodness of fit hasil pengujian signifikansi model dilaksanakan dalam pengujian Chi-Square (model dinyatakan baik apabila semakin kecil nilai $\chi 2$, dan bisa diterima berasaskan probabilitas dengan cut-off value sebesar p>0,05 atau p>0,010), GFI (Goodness of fit Index), CFI (Comparative Fit Index), AGFI (Adjusted Goodness of Fit Index), RMSEA (Root Mean Square Error of Approximation), TLI (Tucker Lewis Index), CMIN/DF (The Minimum Sample Discrepancy Function Devided with degree of freedom), adalah statistik chisquare $\chi^{2}$ di bagi dengan degree of freedom-nya maka disebut $\chi^{2}$ relative. Ada beberapa pengujian asumsi evaluasi model struktural yang harus dicermati untuk menentukan kriteria goodness of fit yaitu evaluasi univariate outliar, multivariate ouliar, evaluasi normalitas data, dan evaluasi Multikolinearitas (Ghozali, 2017).

\section{HASIL DAN PEMBAHASAN}

Karakteristik responden sebagai subjek dalam penelitian ini dapat dilihat dalam Tabel 1.

Tabel 1.Kesimpulan Karakteristik Responden

\begin{tabular}{|c|c|c|c|}
\hline No & Karakteristik & Hasil & Presentase \\
\hline \multirow{2}{*}{1.} & \multirow{2}{*}{ Jenis Kelamin } & Wanita & $57 \%$ \\
\hline & & Laki-laki & $43 \%$ \\
\hline \multirow{2}{*}{2.} & \multirow{2}{*}{ Usia } & 17-19 tahun & $52 \%$ \\
\hline & & $20-23$ tahun & $48 \%$ \\
\hline 3. & Pekerjaan & Mahasiswa/i & $100 \%$ \\
\hline \multirow{2}{*}{4.} & \multirow{2}{*}{$\begin{array}{l}\text { Intensitas mengikuti seminar/pelatihan } \\
\text { kewirausahaan }\end{array}$} & $\geq 5$ kali & $40 \%$ \\
\hline & & $\geq 6$ kali & $60 \%$ \\
\hline \multirow{3}{*}{5.} & \multirow{3}{*}{ Model usaha yang dijalankan } & Offline Store & $14 \%$ \\
\hline & & Online Store & $32 \%$ \\
\hline & & Mix (offline+online) Store & $54 \%$ \\
\hline
\end{tabular}

Sumber: Data primer yang diolah (2021)

Pada penelitian ini terdapat 100 orang responden yang terdiri dari mahasiswa politeknik negeri semarang yang mewakili populasi mahasiswa yang menjalankan usaha kewirausahaan di tengah pembelajaran mereka seperti yang disajikan pada tabel 1 menjelaskan bahwa 60\% mahasiswa polines telah mengikuti seminar maupun pelatihan kewirausahaan lebih dari enam 
(6) kali, itu menandakan intensitas penggunakan seminar maupun pelatihan kewirausahaan oleh mahasiswa polines cukup tinggi yang menandakan minat dan keinginan mereka untuk berwirausaha cukup untuk dijadikan acuan penelitian.

\section{Evaluasi Normalitas Data}

Assessment of normality merupakan output untuk menguji apakah data terdistribusi secara normal sebagai syarat asumsi yang harus dipenuhi dengan Maximum Likehood. Normalitas secara univariat dapat di lihat dari besaran nilai Critical Ratio (CR) dari skewness dan Critical Ratio $(\mathrm{CR})$ dari kurtosis dengan rentang $\pm 2,58$ dan dan Normalitas secara multivariate dapat dilihat di kolom paling bawah Critical Ratio (CR) dari kurtosis dengan rentang $\pm 2,58$ pada tingkat signifikansi 0.01 (Ghozali, 2017). Adapun normalitas data melalui AMOS 24 sebagaimana disajikan pada Tabel 2.

Tabel 2. Assessment of normality

\begin{tabular}{|l|llllll|}
\hline Variable & $\min$ & $\max$ & skew & c.r. & kurtosis & c.r. \\
\hline BP1 & 2,000 & 5,000 &, 140 &, 572 &,- 721 & $-1,472$ \\
IE1 & 1,000 & 5,000 &, 088 &, 361 &,- 419 &,- 855 \\
ET1 & 1,000 & 5,000 &, 028 &, 114 &,- 488 &,- 997 \\
ET2 & 2,000 & 5,000 &, 172 &, 702 &,- 527 & $-1,075$ \\
IE4 & 2,000 & 5,000 &, 163 &, 665 &,- 735 & $-1,501$ \\
IE3 & 2,000 & 5,000 &, 307 & 1,253 &,- 162 &,- 330 \\
IE2 & 2,000 & 5,000 &, 266 & 1,086 &,- 531 & $-1,083$ \\
BP2 & 2,000 & 5,000 &, 165 &, 674 &,- 588 & $-1,200$ \\
BP3 & 2,000 & 5,000 &, 086 &, 352 &,- 837 & $-1,708$ \\
BP4 & 2,000 & 5,000 &, 113 &, 462 &,- 585 & $-1,193$ \\
ET4 & 2,000 & 5,000 &,- 020 &,- 080 &,- 623 & $-1,272$ \\
ET3 & 2,000 & 5,000 &, 236 &, 962 &,- 573 & $-1,170$ \\
EU4 & 2,000 & 5,000 &, 155 &, 631 &,- 733 & $-1,496$ \\
EU3 & 1,000 & 5,000 &, 174 &, 710 &,- 441 &,- 900 \\
EU2 & 2,000 & 5,000 &, 268 & 1,095 &,- 577 & $-1,178$ \\
EU1 & 1,000 & 5,000 &, 140 &, 573 &,- 633 & $-1,291$ \\
Multivariate & & & & & 5,850 & 1,219 \\
\hline
\end{tabular}

Sumber: Data primer yang diolah (2021)

\section{Evaluasi Univariate \& Multivariate Outlier}

Mahalanobis Distance guna mengukur ada tidaknya data yang menjadi outlier yaitu dengan melihat skor observasi yang sangat berbeda dengan skor centroid untuk 100 kasus. Dari hasil pengolahan data didapatkan jarak minimal mahalanobis yang tertera yaitu sebesar 7,286 serta jarak maksimal ialah 31,486. Data outlier dipersepsikan dari nilai mahalanobis yang melebihi nilai chi-square. Dalam penelitian ini chi-square dari derajat kebebasan 16 (jumlah indikator variabel) pada tingkat signifikansi 0,001 yaitu 32.000 maka dinyatakan tidak terdapat outlier (Ghozali, 2017).

\section{Evaluasi Multikolinearitas}

Menurut (Hair et al, 2010) gejala multikolineritas bisa di lihat melalui matrix sample correlations, jika nilai yang dihasilkan dari tiap-tiap indikator lebih kecil dari $(<) 0,90$ maka dapat dinyatakan tidak terdapat gejala multikoleniaritas. Hasil olah data pada penelitian ini menunjukkan tidak adanya gejala multikolinearitas pada matrix sample correlations. 
Tabel 3. Matrix Sample Correlations

\begin{tabular}{|c|c|c|c|c|c|c|c|c|}
\hline & BP1 & IE1 & ET1 & ET2 & IE4 & IE3 & IE2 & BP2 \\
\hline BP1 & 1,000 & & & & & & & \\
\hline IE1 & ,618 & 1,000 & & & & & & \\
\hline ET1 & ,561 & ,643 & 1,000 & & & & & \\
\hline ET2 & ,601 & ,634 & ,541 & 1,000 & & & & \\
\hline IE4 & ,597 & ,515 & ,547 & ,497 & 1,000 & & & \\
\hline IE3 & ,537 & ,572 & ,564 & ,556 & ,484 & 1,000 & & \\
\hline IE2 & ,624 &, 543 & ,670 & ,530 & ,559 & ,477 & 1,000 & \\
\hline BP2 & ,428 & ,564 & ,597 & ,568 & ,602 & ,594 & ,606 & 1,000 \\
\hline BP3 & ,529 & ,630 & ,674 & ,505 & ,573 & ,591 & ,620 & ,449 \\
\hline BP4 & ,550 & ,615 & ,542 & ,639 & ,594 & ,649 & ,471 & ,595 \\
\hline ET4 & ,686 & ,608 & ,498 & ,643 & ,513 & ,601 & ,559 & ,521 \\
\hline ET3 & ,537 & ,591 & ,502 & ,481 & ,670 & ,579 &, 573 & ,613 \\
\hline EU4 & ,619 & ,532 & ,509 & ,487 & ,684 & ,516 & ,578 & ,613 \\
\hline EU3 & ,671 & ,679 & 609 & ,626 & ,593 & ,654 & ,617 & ,531 \\
\hline EU2 & ,627 & ,644 & ,556 & ,625 & ,516 & ,564 & ,602 & ,584 \\
\hline EU1 & ,681 & ,705 & ,785 & ,628 & ,558 & ,681 & ,680 & ,592 \\
\hline & BP3 & BP4 & ET4 & ET3 & EU4 & EU3 & EU2 & EU1 \\
\hline BP3 & 1,000 & & & & & & & \\
\hline BP4 & ,449 & 1,000 & & & & & & \\
\hline ET4 & ,503 & ,681 & 1,000 & & & & & \\
\hline ET3 & ,561 & ,546 & ,478 & 1,000 & & & & \\
\hline EU4 & ,506 & ,527 & ,577 & ,784 & 1,000 & & & \\
\hline EU3 & ,645 & ,644 & ,616 & ,598 & ,502 & 1,000 & & \\
\hline EU2 &, 573 & ,585 &, 673 & ,541 &, 575 & 4995 & 1,000 & \\
\hline EU1 & ,699 & ,601 & ,647 & ,598 & ,537 & ,659 & ,560 & 1,000 \\
\hline
\end{tabular}

Sumber: Data primer yang diolah (2021)

\section{Interpretasi dan Modifikasi Model}

Esensi dari SEM ialah penentuan fit antara restricted covariance matrix dan sample covariance matrix, maka suatu model penelitian dinyatakan baik, ketika nilai dari Standardized Residual Covariance adalah tidak melebihi 2,58 (Ghozali, 2017). Hasil Standardized Residual Covariance pada output model penelitian menunjukkan tidak ada nilai yang melebihi dari standar yang telah ditentukan.

\section{Hasil Pengujian Model Persamaan Struktural}

Dalam penelitian ini dibentuklah model persamaan struktural menggunakan aplikasi AMOS 24 dengan tiga konstruk atau variabel latent yang terdiri dari orientasi kewirausahaan, adaptablitas lingkungan dan kinerja bisnis UKM dengan masing-masing variabel latent diukur oleh empat variabel manifest (Ghozali, 2017).

Tabel 4. Kriteria Cut Value Hasil Evaluasi

\begin{tabular}{|l|l|l|l|}
\hline Goodness-of-fit index & Cut of Value & Hasil Analisis & Evaluasi Model \\
\hline Chi-Square & $\leq 114.267$ & 102.907 & Baik \\
\hline Probability & $\geq 0.05$ & 0.185 & Baik \\
\hline GFI & $\geq 0.90$ & 0.888 & Marginal \\
\hline AGFI & $\geq 0.90$ & 0.833 & Marginal \\
\hline TLI & $\geq 0.90$ & 0.987 & Baik \\
\hline CFI & $\geq 0.90$ & 0.990 & Baik \\
\hline DF & $\leq 2.00$ & 91 & Baik \\
\hline RMSEA & $\leq 0.08$ & 0.036 & Baik \\
\hline
\end{tabular}

Sumber: Data primer yang diolah (2021) 
Hasil pengujian terhadap kriteria goodness of fit dalam program AMOS 24 menunjukan bahwa analisis structural equation modeling dalam penelitian ini dapat diterima sesuai dengan model fit dengan nilai Chi-square $=102,907$, Probabilitas $=0,185$ DF $=91$, GFI $=0.888$, AGFI $=$ 0,833, CFI $=0,990$, TLI $=0,987$ dan RSMEA $=0,036$. Berdasarkan model fit ini dapat disimpulkan bahwa model memenuhi kriteria goodness of fit. Oleh karena itu model persamaan strutural pada penelitian ini cocok dan layak untuk digunakan sehingga dapat dilakukan interpresi guna pembahasan lebih lanjut (Ghozali, 2017). sebagaimana disajikan pada Tabel 4.

Tabel 5 Regression Weights

\begin{tabular}{|c|c|c|c|c|c|c|}
\hline & & & Estimate & S.E. & C.R. & $\mathrm{P}$ \\
\hline Interest_in_Entrepreneurship & $<--$ & Entrepreneurship_Understanding &, 538 & , 106 & 5,061 & $* * *$ \\
\hline Interest_in_Entrepreneurship & $<---$ & Entrepreneurship_Training &, 503 &, 113 & 4,454 & $* * *$ \\
\hline Business_Productivity & $<---$ & Interest_in_Entrepreneurship &, 361 &, 107 & 3,357 & $* * *$ \\
\hline Business_Productivity & $<---$ & Entrepreneurship_Understanding & ,414 & ,090 & 4,584 & $* * *$ \\
\hline Business_Productivity & $<---$ & Entrepreneurship_Training & ,257 &, 100 & 2,571 & 010 \\
\hline EU1 & $<---$ & Entrepreneurship_Understanding & 1,000 & & & \\
\hline EU2 & $<---$ & Entrepreneurship_Understanding &, 866 & 100 & 8,689 & $* * *$ \\
\hline EU3 & $<---$ & Entrepreneurship_Understanding & ,975 & 102 & 9,531 & $* * *$ \\
\hline EU4 & $<---$ & Entrepreneurship_Understanding & ,797 & ,098 & 8,107 & $* * *$ \\
\hline BP4 & $<---$ & Business_Productivity & ,890 &, 114 & 7,780 & $* * *$ \\
\hline IE2 & $<---$ & Interest_in_Entrepreneurship & ,944 &, 113 & 8,349 & $* * *$ \\
\hline ET1 & $<---$ & Entrepreneurship_Training & 1,000 & & & \\
\hline BP2 & $<---$ & Business_Productivity & ,893 &, 115 & 7,793 & $* * *$ \\
\hline BP3 & $<---$ & Business_Productivity & ,993 &, 122 & 8,131 & $* * *$ \\
\hline IE3 & $<---$ & Interest_in_Entrepreneurship & ,819 &, 101 & 8,119 & $* * *$ \\
\hline IE4 & $<---$ & Interest_in_Entrepreneurship &, 881 &, 111 & 7,970 & $* * *$ \\
\hline IE1 & $<---$ & Interest_in_Entrepreneurship & 1,000 & & & \\
\hline BP1 & $<---$ & Business_Productivity & 1,000 & & & \\
\hline ET4 & $<---$ & Entrepreneurship_Training & ,908 &, 115 & 7,864 & $* * *$ \\
\hline ET3 & $<---$ & Entrepreneurship_Training & ,947 &, 124 & 7,625 & $* * *$ \\
\hline ET2 & $<---$ & Entrepreneurship_Training & ,886 &, 121 & 7,305 & $* * *$ \\
\hline
\end{tabular}

Sumber: Data primer yang diolah (2021)

Hasil penelitian dari empat variabel diatas pada mahasiswa politeknik negeri semarang dengan 100 orang responden sebagai sampel dari keseluruhan populasi dapat dilihat dari hasil output pada Regression Weights yang menerangkan bahwa setiap indikator atau variabel manifest yang mencerminkan variabel latent memiliki nilai critical ratio $(\mathrm{CR})$ lebih besar (>) dari 1,96 sama dengan nilai t pada regresi (>)1,96 dan $\mathrm{P}$ (Probabilitas signifikansi) dengan $* * *$ berarti by default signifikan pada 0.001. Hasil output hubungan struktural dari empat konstruk menunjukkan bahwa pemahaman kewirausahaan berpengaruh positif terhadap minat berwirausaha dengan nilai estimasi sebesar 0,534 dan signifikan pada $p$-value yang dihasilkan (kolom P) berupa tiga buah asterik $(* * *)$ yang berarti nilainya sangat kecil $(<0,001)$ (Ghozali, 2017). Kemudian pelatihan kewirausahaan berpengaruh positif terhadap minat berwirausaha dengan koefisien standardized sebesar 0,503 dan signifikan pada $p$-value dengan kode asterik $(* * *)$. Kemudian minat berwirausaha berpengaruh positif terhadap produktivitas usaha dengan koefisien standardized sebesar 0,361 dan signifikan pada $p$-value dengan kode asterik (***). Kemudian pelatihan kewirausahaan berpengaruh positif terhadap produktivitas usaha secara langsung dengan koefisien standardized sebesar 0,257 dan signifikan pada p-value $(0,010)$. Kemudian pemahaman kewirausahaan berpengaruh positif terhadap produktivitas usaha dengan koefisien standardized sebesar 0,414 dan signifikan pada $p$-value dengan kode asterik 
(***). Kemudian untuk setiap variabel manifest juga mempunya nilai $p$-value dengan kode asterik $(* * *)$ yang berarti nilainya sangat kecil $(<0,001)$ terhadap variabel latent, ini berarti semua indikator/ variabel manifest tersebut dapat menjelaskan variabel latent dengan sangat baik (Ghozali, 2017) sebagaimana disajikan pada Tabel 5 Regression Weights.

\section{KESIMPULAN}

Pertumbuhan pemahaman kewirausahaan pada seseorang berpengaruh positif terhadap peningkatan minat berwirausaha mahasiswa Politeknik Negeri Semarang. Kondisi ini dibuktikan dengan diterapkaannya pendidikan pemahaman kewirausahaan yang ada pada mahasiswa di lembaga Politeknik Negeri Semarang mampu menguatkan minat berwirausaha mahasiswa dalam melakukan bisnis, sehingga apa yang dilakukan mahasiswa dengan meningkatkan pemahaman berwirausaha berdampak pada peningkatan minat berwirausaha dalam kegiatan bisnis. Hasil ini selaras dengan penelitian Aditya dan Ketut (2016), Herwin Saputri (2016) yang mengatakan bahwa peningkatan pemahaman kewirausahaan mempunyai pengaruh pasitif dan signifikan terhadap minat berwirausaha, pernyataan yang sama juga diungkapkan oleh Ni Made Sintya (2019) dalam penelitiannya yang menyatakan bahwa pemahaman kewirausahaan berpengaruh positif terhadap minat berwirausaha bagi peserta pelatihan kewirausahaan mandiri.

Pelatihan dan seminar kewirausahaan berpengaruh positif dan signifikan terhadap minat berwirausaha mahasiswa program pengembangan kewirausahaan. Selaras dengan hasil penelitian Lestari, dkk (2016) dan Lubis, R. L. (2015) yang mengatakan bahwa pelatihan kewirausahaan berpengaruh positif dan signifikan terhadap peningkatan minatberwirausaha, semakin sering dilakukan pelatihan kewirausahaan, maka akan semakin menguatkan minat berwirausaha bagi pelaku usaha. Sejalan dengan penelitian Mahesa dan Rahardja (2016)yang menunjukkan bahwa pelatihan kewirausahaan berpengaruh positif terhadap minat berwirausaha. Berarti semakin tinggi tingkat pelatihan kewirausahaan, maka akan mampu meningkatkan minat berwirausaha bagi mahasiswa program pengembangan kewirausahaan.

Pemahaman kewirausahaan berpengaruh positif dan signifikan terhadap produktivitas usaha. Semakin tinggi tingkat pemahaman kewirausahaan akan menjadi dasar untuk meningkatkan produktivitas usaha bagi mahasiswa program pengembangan kewirausahaan Politeknik Negeri Semarang. Sejalan dengan penelitian Retno, dkk (2017), menunjukkan bahwa penguatan pemahaman kewirausahaan berpengaruh positif dan signifikan terhadap produktivitas usaha, artinya apabila pendidikan pemahaman kewirausahaan semakin ditingkatkan maka akan mampu meningkatkan produktivitas usaha bagi mahasiswa. Hasil penelitian yang sama juga diungkapkan oleh Sahban (2016), Asep Munawar (2018) yang menyatakan bahwa pemahaman kewirausahaan berpengaruh positif dan signifikan terhadap produktivitas usaha.

Pelatihan kewirausahaan berpengaruh positif dan signifikan terhadap produktivitas usaha. Semakin tinggi pelaksanaan pelatihan kewirausahaan akan mampu meningkatkan produktivitas usaha bagi mahasiswa program penggembangan kewirausahaan Politeknik Negeri Semarang. Sejalan dengan hasil penelitian Sukirman (2017), yang menguji pengaruh pelatihan kewirausahaan terhadap produktivitas usaha, menunjukkan bahwa pelatihan kewirausahaan berpengaruh pasitif terhadap peningkatan produktivitas usaha. Berarti pelatihan kewirausahaanperlu dikembangkan agar terbentuknya produktivitas usaha mahasiswa semakin kuat. Pernyataan yang sama juga diungkapkan oleh Tjipto dan Subroto (2016) yang menyatakan bahwa pelatihan kewirausahaan berpengaruh pasotif dan signifikan terhadap produktivitas usaha. Didukung hasil penelitian Aditya dan Ketut (2016), yang mengatakan bahwa peningkatan minat berwirausaha berpengaruh terhadap peningkatan produktivitas 
usaha, sehingga diperlukan upaya agar minat berwirausaha semakin meningkat. Selain itu juga diungkapkan oleh Diajeng Galuh Chandra Kirana (2018), Josia Sanchaya Hendrawan (2017) yang menyatakan bahwa minat berwirausaha berpengaruh terhadap peningkatan produktivitas usaha.

Penelitian ini menunjukkan bahwa pemahaman kewirausahaan memiliki peran dalam meningkatkan produktivitas usaha antara lain ialah memperkuat pengaruh peningkatan produktivitas usaha mahasiswa dalam kewirausahaan, Serta pemahaman kewirausahaan dan pelatihan kewirausahaan mampu membuktikan peningkatan produktivitas usaha mahasiswa melalui minat berwirausaha. Pemahaman kewirausahaan perlu ditingkatkan supaya lebih menguatkan produktivitas usaha mahasiswa dalam menghadapi gelombang pengangguran saat ini, sehinggan terbentuk wirausaha-wirausaha muda yang berdampak terhadap peningkatan pendapatan dan akhirnya mampu meningkatkan perekonomian masyarakat. Diperlukan adanya peningkatan pelatihan kewirausahaan bagi mahasiswa guna pengembangan usaha, sehingga mempermudah dalam pengelolaan manajemen usaha, perluasan pasar, penggembangan produk guna mengantisipasi terjadinya kegagalan dalam menjalankan usaha. kondisi ini harus dikembangkan sehingga kemampuan pengembangan usaha dapat berjalan lancar dan semakin meningkat.

\section{DAFTAR PUSTAKA}

Aditya, W dan Ketut, G. (2016). Peran Pendidikan Kewirausahaan dalam Memediasi Pengaruh Norma Subyektif terhadap Niat Berwirausaha. E-Jurnal Manajemen Unud 5: 533-560. Fakultas Ekonomi dan Bisnis Universitas Udayanan. Bali.

Asep Munawar. (2018). Pengaruh Sikap Dan Motivasi Terhadap Minat Berwirausaha Siswa. Oikos : Jurnal Kajian Pendidikan Ekonomi dan Ilmu Ekonomi, ISSN Online : 2549- 2284 Volume II Nomor 1, Mei 2018

Diajeng Galuh Chandra Kirana. (2018). Pengaruh Pendidikan Kewirausahaan dan Self Efficacy Terhadap Minat Berwirausaha (Studi Pada Mahasiswa Program Studi Pendidikan Ekonomi Tahun Angkatan 2014-2016). BISE: Jurnal Pendidikan Bisnis dan Ekonomi https://jurnal.uns.ac.id/bise p-ISSN 2548-8961 | e-ISSN 2548-7175 | Volume 4 Nomor 1 (2018).

Ghozali, Imam. 2017. Model Persamaan Struktural Konsep dan Aplikasi dengan Program AMOS 24 Edisi 7. Semarang: BP UNDIP.

Hair, J.F., Black, W.C., Babin, B.J., \& Anderson, R.E. 2010. Multivariate Data Analysis. Seventh Edition. Prentice Hall, Upper Saddle River, New Jersey.

Herwin Saputri. (2016). Pengaruh Motivasi Berwirausaha Terhadap Minat Berwirausaha Melalui Prestasi Belajar Mata Pelajaran Kewirausahaan Siswa Kelas XI SMK Negeri 1 Kraksaan. Jurnal Pendidikan Bisnis dan Manajemen, Volume 2, Nomor 2, September 2016, Halaman 123-132.

Josia Sanchaya Hendrawan. (2017). Pengaruh Sikap Mandiri, Motivasi, Pengetahuan Kewirausahaan terhadap Minat Berwirausaha (Studi Kasus pada Mahasiswa FEB UKSW Konsentrasi Kewirausahaan). AJIE - Asian Journal of Innovation and Entrepreneurship (eISSN: 2477- 0574 ; p-ISSN: 2477-3824) Vol. 02, No. 03, September 2017.

Lestari, Retno B., dan Trisnadi, W. (2016). Pengaruh Pendidikan Kewirusahaan Terhadap Minat Berwirausaha Mahasiswa Di STIE MDP, STIKA MDP, DAN STIE MUSI, Jurnal Ilmiah STIE MDP, Vol, 1 No, 2, Maret 2016, Hal, 112-119.

Lubis, R. L. (2015). The Triple-I Learning Model of Entrepreneurship Education in Indonesia: Where Do We Go From Here International Journal of Arts \& Sciences, 8(7), 233-264.

Mahesa, A dan Rahardja, E. (2016). Analisis faktor-faktor motivasi yang mempengaruhi minat berwirausaha. Diponegoro journal of managament. Vo, 1, No. 1, Hal, 130-137. 
Ni Made Sintya. (2019). Pengaruh Motivasi, Efikasi Diri, Ekspektasi Pendapatan, Lingkungan Keluarga, dan Pendidikan Kewirausahaan terhadap Minat Berwirausaha Mahasiswa Jurusan Akuntansi di Universitas Mahasaraswati Denpasar. Jurnal Sains, Akuntansi dan Manajemen (Vol. 1, No. 1: Januari, 2019).

Retno, Budi L., dan Trisnadi Wijaya. (2017). Pengaruh Pendidikan Kewirausahaan Terhadap Minat Berwirausaha Mahasiswa di STIE MDP, STMIK MDP, dan STIE MUSI . Jurnal Ilmiah STIE MDP.

Sahban, M. A., Ramalu, S. S., and Syhputra, R. (2016). The influence of social support on entrepreneurial inclination among business students in Indonesia. Journal Information Management Business Review, 8(3), 32-46.

Setyawan, N. A. (2021) 'The Existence of Lasem Batik Entrepreneurs during the Covid-19 Pandemic', Admisi dan Bisnis, 22, pp. 61-72. Available at: https://jurnal.polines.ac.id/index.php/admisi/article/view/2490.

Stauffer, D. (2016). Personal innovativeness as a predictor of entrepreneurial value creation. International Journal of Innovation Science, p. 4 - 26.

Sukirman. (2017). Jiwa Kewirausahaan Dan Nilai Kewirausahaan Meningkatkan Kemandirian Usaha Melalui Perilaku Kewirausahaan, Jurnal Ekonomi dan Bisnis Vol. 20 No. 1. H. 113132

Tjipto, W., and Subroto. (2016). Entreprenenurship Development Course To Foster Character Merchandise In Support Economic Groeth European Journal of Business and Innovation Research , Vol. I, No.1, March 2014, pp.1-9

Yulius David Andi. (2016). Personal Influence, Entrepreneurship Training and Entrepreneurship Knowledge on Entrepreneurship Interest, with Competitive Advantages As Intervening Variables (Study Case in the Karanggondang Village Community of Jepara Regency). Asian Journal of Innovation and Entrepreneurship Vol. 01, No. 04, September 2016 